\title{
DMF-T index and performed treatment index of patients in Conservative Dentistry Installation
}

\author{
Muhammad Adri Nurrahim*, Endang Sukartini*, Ayu Trisna Hayati* \\ *Department of Operative Dentistry Faculty of Dentistry Universitas Padjadjaran
}

\begin{abstract}
Introduction: DMF-T index is an important indicator to assess oral health status of the population. DMF-T index is a number that indicates the average total number of permanent teeth affected by caries, missing or should be extraction because of caries, or have been restorated on each tooth and not each surface. DMF-T index being a reference of the Performed Treatment Index (PTI) which is the sum percentage of restored teeth or without caries in the population. The purpose of this study is to determine DMF-T index and performed treatment index of the patient in Dental Conservation Installation.Methods: This research used the descriptive with survey techniques. Sampling was conducted with a total sampling. The DMF-T index and PTI of Patients in Dental Conservative Installation on July - September 2011. The data obtained through clinical examination of 561 respondents. Results: The DMF-T index patients in Dental Conservative Installation is 5.824 while the PTI is $1.51 \%$. Conclusion: DMF-T index of patients in Dental Conservative Installation period July - September 2011 in the high category and PTI Patients In Dental Conservative Installation Oral and Dental Hospital Faculty of Dentistry Universitas Padjadjaran period July - September 2011 in the low category.
\end{abstract}

Keywords: Caries, DMF-T Index, PTI, Performance Treatment Index

\section{INTRODUCTION}

Dental health is part of the general health. The ability to live healthy means to have a healthy body with optimal quality, including conditions that are free of all diseases as well as dental oral disease. The oral cavity of human need care because the oral cavity is very susceptible to disease, so dental oral care is very important, to maintain a good quality of health. ${ }^{1}$

The Ministry of Health $(\mathrm{MOH})^{2}$ released 2007 Basic Health Research (Riskerdas) data which disclosed that $72 \%$ of Indonesia's population has $46.5 \%$ cavities (caries) experience of which were untreated active caries. ${ }^{2}$ The DMF-T National Index Result was 4.85, while the DMF-T index of West Java was 4.03. The largest tooth loss component was the molar tooth. Based on the results of the National DMF-T Index and the DMF-T index of West Java, it can be said that on average every Indonesian people as well as the population of West Java has 4 to 5 missing or damaged teeth. The PTI (Performance Treatment Index) of people in Indonesia and West Java currently showed a figure of $1.6 \%$. This PTI value was very little when compared with the value of RTI or the percentage of teeth that require treatment which showed $33.8 \% .^{2}$

Correspondence author: Muhammad A.N, Department of Operative Dentistry. Faculty of Dentistry Universitas Padjadjaran Jl. Sekeloa Selatan No.1 Bandung, West Java-Indonesia, Tel./Fax.+6222-2504985/2532805 
Dental caries is the most common case, which causes the patient to visit the dentist in addition to cases of gum disease and tooth loss. Based on the data from World Oral Health, it is stated that 5 million people in the world suffer from cavities. Dental caries is an infectious disease, which causes damage to the localized hard tissues. This infectious diseases are caused by microbial metabolic acid which is the process of fermentation of sugary foods into organic acids. ${ }^{3}$ World Health Organization (WHO) states that the status of dental health in the community can be seen by calculating the DMF-T Index which is an important indicator in viewing the dental health status of the community. The value of DMF-T Index in the community can act as a reference in motivating an individual to do tooth filling for a cavity to retain permanent teeth by calculating the percentage of PTI or called Performance Treatment Index. ${ }^{4,2}$ The purpose of this study is to determine DMF-T index and performed treatment index of the patient in Dental Conservation Installation.

\section{METHODS}

The research method used in this research was descriptive research with survey technique. The population of this research were patients who came to visit Dental Conservation Installation Dental Conservative Installation Oral and Dental Hospital Faculty of Dentistry Padjadjaran University Sekeloa Selatan Bandung from July to September 2011. The population criteria were male \& female patients aged 14-25 years, not illiterate, patients were willing to take part in the research. The sampling technique is a total sampling.

\section{RESULTS}

This research was conducted at Dental Conservative Installation Oral and Dental Hospital Faculty of Dentistry Padjadjaran University in July - September 2011. The researchers obtained a sample of 559 respondents aged 14-25 years, consisting of 216 male respondents and 343 female respondents. DMF-T and PTI indexes were obtained through clinical examination in patients. The result of the clinical examination was recorded in the odontogram sheet, and calculations of DMF-T and PTI Indexes were performed, as shown in tables 1 and 2 .

Table 1 showed the number of cariesaffected teeth (D), which were 2021 teeth, missing teeth or extracted teeth due to caries $(M)$ were 743 teeth, and teeth have been filled $(F)$ were 492 teeth from total number of 559 respondents. The result of DMF-T index in patients in Dental Conservative Installation Oral and Dental Hospital Faculty of Dentistry Padjadjaran University was 5.824 , which mean that in average, every patient in Dental Conservation Installation Oral and Dental Hospital Faculty of Dentistry Padjadjaran University suffered from defect or lost 5-6 teeth. Based on WHO's criteria, the results of DMF-T Index of patients in Dental Conservative Installation Oral and Dental Hospital Faculty of Dentistry Padjadjaran University were included in the high category.

PTI is the percentage of the total number of teeth that is filled on the patient. PTI calculations was performed by dividing the total number of filled teeth or $F$ (Filled) obtained from the

Table 1. DMF-T index of patients in dental conservative installation oral and Dental hospital Faculty of Dentistry Universitas Padjadjaran

\begin{tabular}{cccccccc}
\hline & \multicolumn{3}{c}{ Total } & Total D $+M+F$ & Total Respondent & DMF-T Index & Category \\
\hline & D & $M$ & $F$ & & & & \\
\hline Respondent & 2021 & 743 & 492 & 3256 & 559 & 5.824 & High \\
\hline
\end{tabular}

Table 2. PTI of Patients In Dental Conservative Installation Oral And Dental Hospital Faculty of Dentistry Universitas Padjadjaran

\begin{tabular}{cccccc}
\hline & Total & Total $\mathrm{D}+\mathrm{M}+\mathrm{F}$ & Total Respondent & PTI & Category \\
\cline { 2 - 5 } & $\mathrm{F}$ & & & & \\
\hline Respondent & 492 & 3256 & 559 & $1,51 \%$ & Low \\
\hline
\end{tabular}


examination by the total number of DMF-T and multiplied by $100 \%$, as shown in table 2 .

Table 2 showed the total number of teeth that have been filled $(F)$ were 492 teeth from the total sample of 559 respondents. The result of PTI index of patients in Dental Conservative Installation Oral and Dental Hospital Faculty of Dentistry Universitas Padjadjaran is $1.51 \%$, which mean that the level of public awareness motivation in maintaining dental ora health is still very low. Based on the standard objective criteria Arikunto, the results of PTI patients in the Dental Conservative Installation Oral and Dental Hospital Faculty of Dentistry Universitas Padjadjaran were included in the low category.

\section{DISCUSSION}

The results of the research on the patient in the Dental Conservative Installation Oral and Dental Hospital Faculty of Dentistry Universitas Padjadjaran have shown that the value of DMF-T index was 5.824. These figures showed that the average tooth decay per person in the patient in Dental Conservative Installation Oral and Dental Hospital Faculty of Dentistry Padjadjaran University was 5-6 teeth. According to WHO (World Health Organization), DMF-T index value in the range of 4.5 to 6.5 is classified as high caries severity. ${ }^{5}$ Based on that category, it can be said that the severity of caries in patients in Dental Conservative Installation Oral and Dental Hospital Faculty of Dentistry Unicersitas Padjadjaran were included in the high category. The results of this study were larger than Riskesdas data in 2007, in which the National DMF-T Index was 4.85, and the DMF-T index in West Java was 4.03. ${ }^{2}$

Research data showed that the total number of caries tooth that has been filled $(F)$ was a little less which was 492 teeth, as compared to the total number of untreated caries tooth (D) which was 2021 teeth. This showed that the low awareness of patients in Dental Conservative Installation Oral and Dental Hospital Faculty of Dentistry Universitas Padjadjaran to maintain dental oral health.

WHO had indicators and standards known as "Oral Global Goal For The Year 2010", the criterion were the 18 years old population with extractionfree teeth (component $M=0$ ), the 35-44 year old population with at least 20 functioning teeth was $90 \%$, and the population of $35-44$ years without edentulous was less than $2 \%$, the population aged 65 and above which still has functioning teeth was $75 \%$, and a toothless population of less than $5 \% .{ }^{6}$ Based on data from the results of the research it can be argued that the patients in the Dental Conservative Installation Oral and Dental Hospital Faculty of Dentistry Universitas Padjadjaran were still below the standards of the health indicators set by WHO.

Clinical examination data showed that the most caries-affected, the most commonly lost, and the most filled were molar teeth, either upper maxillary tooth or lower mandibular teeth. Caries in molar teeth can occur due to the anatomical forms of molar teeth with highly-walled pit and fissures, thus the mechanical cleaning or tooth brushing of the molar teeth is difficult since bristles are difficult to reach that area. This is the reason molar teeth are very susceptible to caries. ${ }^{7}$

Based on Axelsson (2000), caries occurs due to etiological factors, but there are several other factors that influence the prevalence, incidence and development of dental caries. ${ }^{8}$ Factors significantly increasing the incidence and development of caries are referred to as caries risk factors. Caries risk factors include diet, socioeconomic and behavioral, and immune responses.

Respondents aged 14-25 are categorized as adolescents and young adults. Adolescent and young adult groups have eating habits and the habit of maintaining oral hygiene that affects caries risk factors. Various types of food such as fast food, habits of eating between meals, the habit of drinking soft drinks with soda and high sugar content. Fast food contains high carbohydrates and low fiber content. The habit of eating snacks between meals, with no hygiene practice causes insufficient time for the teeth to neutralize the acid formed. Types of soft drinks containing high levels of sugar can cause plaque bacteria to produce acids from fermented carboohydrate and causing dental caries..$^{9,10}$

The socioeconomic level of patients in the Dental Conservative Installation can affect since caries is found to be higher in low socioeconomic groups and vice versa. This is associated with greater interest in healthy living 
in high socioeconomic groups. Low socioeconomic status causes one to not have enough funds and opportunities to use the existing health facilities more optimally, in addition to the inadequate facilities and infrastructure of dental and oral services. Communities' behavior greatly affects the awareness in maintaining dental oral health, in which individual still thinks that to pay a visit the dentist if only experiences toothache. Here it seems that individual in Indonesia has a mindset of curing is better than preventing.

The level of public awareness in maintaining dental oral health also can be seen from the concept of community motivation in an effort to do tooth filling for a cavity in an effort to retain permanent teeth in the oral cavity which is called PTI (Performed Treatment Index). The value of PTI patients in Dental Conservative Installation Oral and Dental Hospital Faculty of Dentistry Universitas Padjadjaran showed $1.51 \%$, while the value of PTI National and West Java was $1.6 \%$. PTI value of both research results above shows the motivation of individuals in West Java in general and Bandung in particular were included in the low category.

The motivation of the community in retaining permanent teeth in the oral cavity by filling cavities is influenced by several factors, such as socioeconomic level, education and knowledge about dental health. The wrong attitude of the community is indicated by the assumption that filling of tooth cavity is not important or the assumption that filling of tooth cavity will only add new problems, so respondents prefer to wait for the destruction of teeth that are already affected by caries. And generally, the community will visit the dentist when there is a disturbing pain complaint.

In Indonesia, the most commonly used filling material is amalgam and composite filling materials. Amalgam has been the preferred restorative material for years because of its low cost, easy to apply, durability, and strength. The use of amalgam is reduced due to aesthetic reasons and harmful effects of mercury. Amalgam restorations can last for 10 to 12 years. ${ }^{11,12}$

The demand and development of restorative materials with similar color to dental tissue such as composite resins are on the rise today. A study conducted by Van Nieuwnhuysen in 2003 has evaluated over 100 composite filling materials, and it was found that the average durability for composite filling materials was 7.8 years. ${ }^{13,14}$

The high index of DMF-T and low PTI in our community indicates the need for efforts to increase a better preventive action so that the motivation of the community in maintaining dental oral health will increase. Public awareness to visit his dentist regularly and motivation to retain permanent teeth longer in the oral cavity is expected to decrease the DMF-T index value and increase the percentage of PTI. The end result of the dental health indicator that has been established by WHO and the Ministry of Health of the Republic of Indonesia can be fulfilled well and the public health status, especially dental and oral health can be increased.

\section{CONCLUSION}

DMF-T index of patients in Dental Conservative Installation period July - September 2011 in the high category and PTI (Performed Treatment Index) Patients In Dental Conservative Installation Oral and Dental Hospital Faculty of Dentistry Universitas Padjadjaran period July September 2011 in the low category.

\section{REFERENCES}

1. Pintauli S, Hamada T. Menuju gigi \& mulut sehat pencegahan dan pemeliharaan. Medan: USU Press, 2008. p. 4-18.

2. Riskesdas. Laporan Hasil Riset Kesehatan Dasar 2007. Jakarta. Badan Penelitian dan Pengembangan Kesehatan. Available from: www.litbang.depkes.go.id/download/ Riskesdas [Cited 4 Jun 2011]. 2007.

3. WHO. Global Goals for the Year 2020. Available from: http://www.whocollab.od.mah.se/ index.html. [Cited 6 Jun 2011].2005.

4. WHO. Oral Health Surveys Basic Methode. $4^{\text {th }}$ ed. Geneva. 1997.

5. Departemen Kesehatan RI. 1999. Rencana Pembangunan Kesehatan Menuju Indonesia Sehat 2010. Jakarta. Dep Kes RI.

6. WHO. The world health report. Available from: https://www.who.int/whr/1995/en/ whr95_en.pdf. [Cited 6 Jun 2011]. 1995.

7. Nikiforuk G. Understanding Dental Caries. 
Prevention Basic and Clinical Aspects. Basel, Karger, 1985;2:I-XIII.

8. Axelsson P. Diagnosis and Risk Prediction of Dental Caries Vol 2. Illinois: Quintessence Publishing Co, Inc. 2000. p. 44-6, 77-80.

9. Dental Practice Education Research Unit of Dental School Aldelaide, 2002?

10. Robin. 23 November 2009. Dental Diet. Available from:http://www.articlealley.com/ article_1243432_17.html [Cited 16 Jul 2011].
11. Leinfelder KF. Do restorations made of amalgam outlast those made of resin-based composite. J Am Dent Assoc 2000;131:1186-7.

12. Anusavice KJ. 2003. Philip's Science of Dental Materials. $11^{\text {th }}$ ed. St. Louis. USA: Elsevier Science. 2003. p. 430-3.

13. Awni M, Al Kayed. A clinical study of placement and replacement of composite restorations in Jordan. Saudi Dental Journal. 1999;11(2):53-9. 